\title{
Two-step synthesis of $\mathrm{MnCo}_{2} \mathrm{~S}_{4}$ nanowires for supercapacitor electrode
}

\author{
Yaşar Özkan YEŞILLBA $\breve{G}^{1 *}$ \\ ${ }^{1}$ Department of Physics, Erzincan Binali Y1ldırım University, Erzincan 24100, Turkey
}

Geliş / Received: 27/07/2020, Kabul / Accepted: 15/12/2020

\begin{abstract}
In this study, $\mathrm{MnCo}_{2} \mathrm{~S}_{4}$ nanowires were synthesized on 3D-Ni foam by the hydrothermal process in two-step and investigated as supercapacitor electrode material. Crystal structure and morphology analyzes of $\mathrm{MnCo}_{2} \mathrm{~S}_{4}$ nanowires were performed. Electrochemical measurements were taken in $1 \mathrm{M}$ of a potassium hydroxide aqueous electrolyte solution. The specific capacitance value calculated from GCD measurement taken at a current density of $0.5 \mathrm{~A} \mathrm{~g}^{-1}$ from the sample was $450 \mathrm{~F} \mathrm{~g}^{-1}$. Furthermore, the sample have good cycling stability by keeping $46 \%$ of the initial specific capacitance after 3000 cycles.
\end{abstract}

Keywords: $\mathrm{MnCo}_{2} \mathrm{~S}_{4}$ nanowires, Hydrothermal method, Supercapacitor

\section{Süperkapasitör elektrot için $\mathrm{MnCo}_{2} \mathrm{~S}_{4}$ nanotellerin iki aşamalı sentezi}

\section{$\ddot{\mathbf{O} z}$}

Bu çalışmada, $\mathrm{MnCo}_{2} \mathrm{~S}_{4}$ nanoteller 3D-nikel köpük üzerinde hidrotermal yöntemle iki aşama da sentezlendi ve süperkapasitör elektrot malzemesi olarak araştırıldı. $\mathrm{MnCo}_{2} \mathrm{~S}_{4}$ nanotellerinin kristal yapısı ve morfoloji analizleri yapıldı. Elektrokimyasal ölçümler $1 \mathrm{M}$ potasyum hidroksit sulu elektrolit çözeltisi yapıldı. $0.5 \mathrm{~A} \mathrm{~g}^{-1}$ akım yoğunluğunda alınan GCD ölçümünden elde edilen spesifik kapasitans değeri $450 \mathrm{~F} \mathrm{~g}^{-1}$ dir. Ayrıca, numune 3000 şarj-deşarj döngüsünden sonra başlangıçtaki spesifik kapasitansın \% 46'sını koruyarak iyi bir döngü kararlılığ 1 gösterdi.

Anahtar Kelimeler: $\mathrm{MnCo}_{2} \mathrm{~S}_{4}$ nanoteller, Hidrotermal yöntem, Süperkapasitör. 


\section{Introduction}

In order to meet the increasing necessity for energy in our daily lives, the need for energy storage devices with high energy and power density, long cycle life and short charging time is increasing day by day (Rolison and Nazar, 2011; Yang et al., 2011; Simon et al., 2014; Yu et al., 2015). Supercapacitors are able to meet these requirements thanks to their high power density, long cycle life, fast charging time and safe operating mode (Burke, 2000). However, it is a major problem that supercapacitors have a lower energy density than rechargeable lithium batteries. In recent years, great improvements were achieved in research on developing supercapacitor performance through the fabrication of electrodes through nanomaterials (Yu et al., 2015).

Many electrode materials (carbons, metal oxides and hydroxides, conductive polymer, and metal sulfides) have been extensively studied for potential application areas of supercapacitors. For example, carbon materials (AC, CNTs and graphene) have been investigated to be used as electrode material in electrical double layer capacitors (Zhang et al., 2014). However, the low capacitance values of electrical double layer capacitors limited the practical applications of these capacitors. On the other hand, transition metal oxides/hydroxides (TMO) and conductive polymers were synthesized as electrode material. The poor conductivity of the transition metal oxides leads to limitation of the power density and reduced cycle performance (Ghosh and Das 2015). To achieve a higher specific capacitance and cyclic performance, it is essential to use electrode materials with high electrical conductivity. However, the low cyclic stability of the conductive polymers also limits their use in practical applications.

Transition metal sulfides have been of great interest in the field of application of supercapacitors. Transition metal sulfides better energy storage with redox reactions on the electrode surface due to their excellent electrical conductivity and chemical activity. In the composite structure of the binary transition metal sulfides (NiS, $\mathrm{CoS}, \mathrm{CoS}_{2}$ and $\mathrm{MoS}_{2}$ ), there is only one transition metal element. On the other hand, there are two different transition metal elements in the composite structure of ternary transition metal sulfides. However, the electrochemical activity of the electrode is increased as more redox reactions occur in ternary transition metal sulfides due to the addition of multiple cations. Further, ternary transition metal sulfides have better electrical conductivity than both ternary transition metal oxides and binary transition metal sulfides. This has led to more extensive investigation of ternary transition metal sulfides in recent years (Peng et al., 2014; Nguyen et al., 2015; Beka et al., 
2016; Moosavifard et al., 2016; Yu et al., 2017).

\section{Materials and Methods}

\subsection{Synthesis of $\mathrm{MnCo}_{2} \mathrm{~S}_{4}$ nanowires}

The synthesis of $\mathrm{MnCo}_{2} \mathrm{~S}_{4}$ nanowires was carried out in two steps (Figure 1). In the first step, $1 \mathrm{mmol} \mathrm{Mn}\left(\mathrm{NO}_{3}\right)_{2} \cdot 4 \mathrm{H}_{2} \mathrm{O}, 2 \mathrm{mmol}$ $\mathrm{Co}\left(\mathrm{NO}_{3}\right)_{2} \cdot 6 \mathrm{H}_{2} \mathrm{O}$, materials were dissolved in a magnetic stirrer in $35 \mathrm{~mL}$ of ionized water for 30 minutes. Subsequently, $2 \mathrm{mmol}$ of $\mathrm{NH}_{4} \mathrm{~F}$ and $5 \mathrm{mmol}$ of $\mathrm{CH}_{4} \mathrm{~N}_{2} \mathrm{O}$ were added to the solution. The nickel foam and the solution were placed in an autoclave and kept at $100{ }^{\circ} \mathrm{C}$ for 12 hours in the oven. After this step the electrode was cleaned with ethanol, deionized water, and dried at room temperature. It was annealed in the tube furnace for 3 hours at $300{ }^{\circ} \mathrm{C}$ to obtain $\mathrm{MnCo}_{2} \mathrm{O}_{4}$ nanowires. In the second step, 0.2 $\mathrm{M}(35 \mathrm{ml}) \mathrm{Na}_{2} \mathrm{~S} . \mathrm{H}_{2} \mathrm{O}$ solution was used for sulphurization of $\mathrm{MnCo}_{2} \mathrm{O}_{4}$ nanowires. $\mathrm{MnCo}_{2} \mathrm{O}_{4}$ electrode was placed into this sulphur solution, and hold in the oven at 120 ${ }^{\circ} \mathrm{C}$ for 12 hours. After the process, the electrode was dried in the oven.

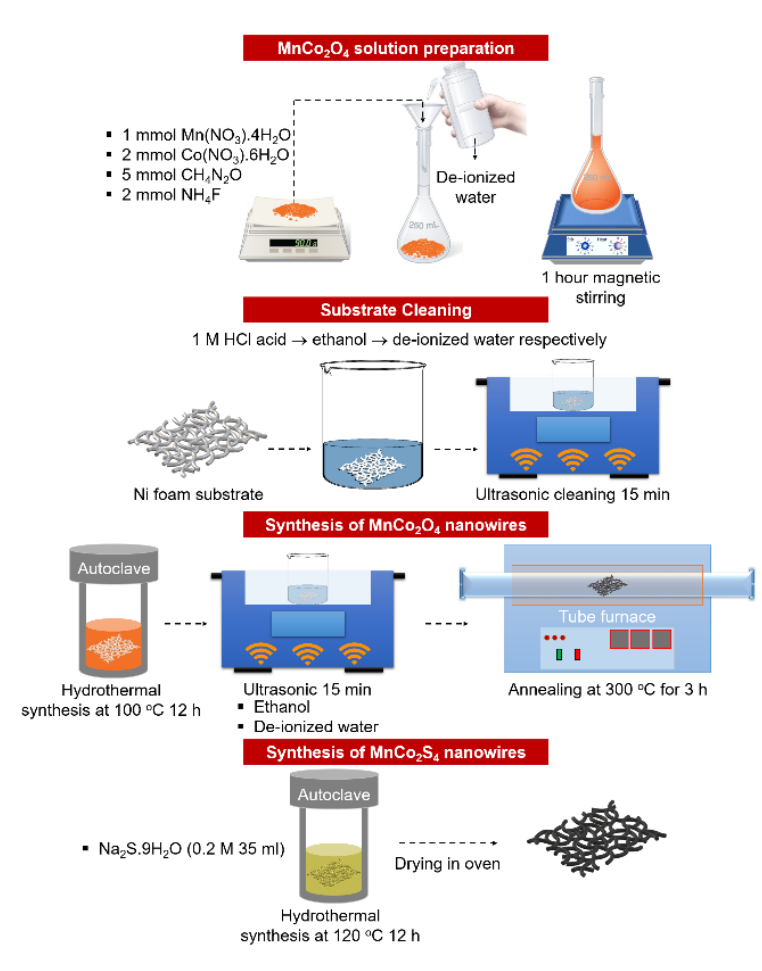

Figure 1. Schematically illustration of the synthesis of $\mathrm{MnCo}_{2} \mathrm{~S}_{4}$ nanowires.

\subsection{Electrochemical analyses of $\mathrm{MnCo}_{2} \mathrm{~S}_{4}$ nanowires}

Electrochemical analyses were taken in a three-electrode test cell. Pt foil and $\mathrm{Hg} /$ $\mathrm{HgCl}$ were used as the counter electrode and reference electrode respectively. Measurements were taken by immersing $1 \mathrm{x} 1$ $\mathrm{cm}^{2}$ of the electrode in $1 \mathrm{M}$ potassium hydroxide. The gravimetric specific capacitance $C$ is calculated by following equation (Xu et al., 2019);

$$
C=\frac{I x t}{m x V}
$$


where I discharge current, $t$ discharge time, $V$ voltage window and $m$ mass of active material. The mass of the active material on the 3D-Ni foam surface was determined by weighed before and after the experiment. $\mathrm{CV}$ and GCD measurements were determined by Gamry Reference 1010E Potentiostat. CV measurements of the sample were taken at different scan rates and GCD measurements were taken at different current densities.

\section{Results and Discussion}

FESEM images and EDS analyses of the sample are shown in Figure 2. In can be seen clear Ni foam uniformly. As seen in Figure 2, the lengths of $\mathrm{MnCo}_{2} \mathrm{~S}_{4}$ nanowires are in the range of $\sim 5-6$ microns. EDS analysis confirmed the presence of $\mathrm{Mn}, \mathrm{Co}, \mathrm{S}, \mathrm{Ni}$ and $\mathrm{O}$ elements in the structure. The atomic concentration of $\mathrm{Mn}, \mathrm{Co}, \mathrm{S}, \mathrm{Ni}$ and $\mathrm{O}$ elements in the structure is $4.44 \%, 26.54 \%$, $35.06 \%, 8.75 \%$ and $25.12 \%$, respectively.

XRD analysis were performed to determine the crystal structure of the electrode material (PANalytical Empyrean, $\mathrm{Cu}-\mathrm{K} \alpha, \lambda=1.54060$ $\AA)$. The diffraction pattern in the range of $20^{\circ}-80^{\circ}(2 \theta)$ is given in Figure 3. As seen in this figure, (220), (311), (222), (400), (422), (511) and (440) are crystal planes of $\mathrm{Co}_{3} \mathrm{~S}_{4}$ nanowires according to JCPDS Card No: 731703. An ion-exchange reaction between the sulpfur source and the precursors Mn, Co has been observed to transform the structure. The peaks of diffraction are similar to those of cubic $\mathrm{Co}_{3} \mathrm{~S}_{4}$ (JCPDS Card no. 73-1703). This also demonstrates that $\mathrm{Co}$ and $\mathrm{Mn}$ ions only change the lattice parameters while retaining the crystal structure where they are (Liu et al., 2017).
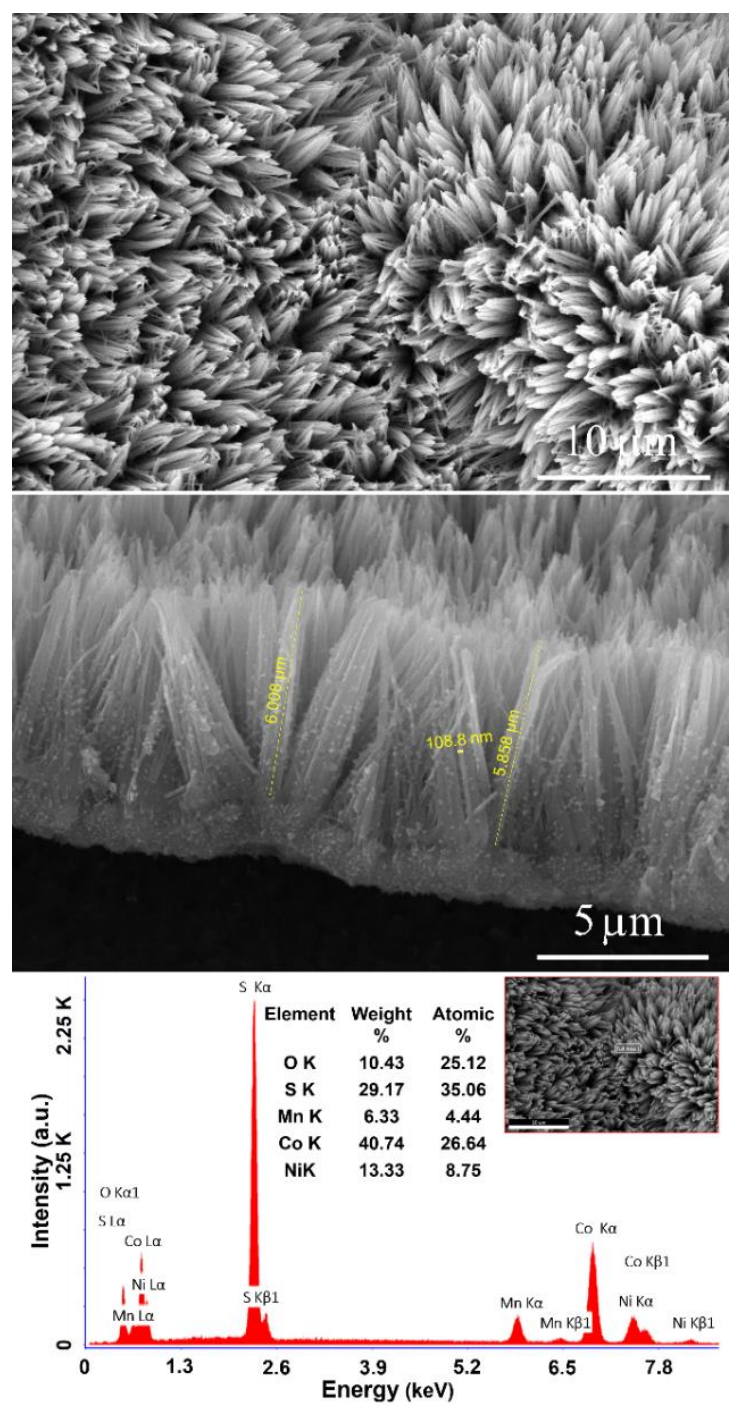

Figure 2. FESEM images of $\mathrm{MnCo}_{2} \mathrm{~S}_{4}$ nanowires and EDS analysis. 


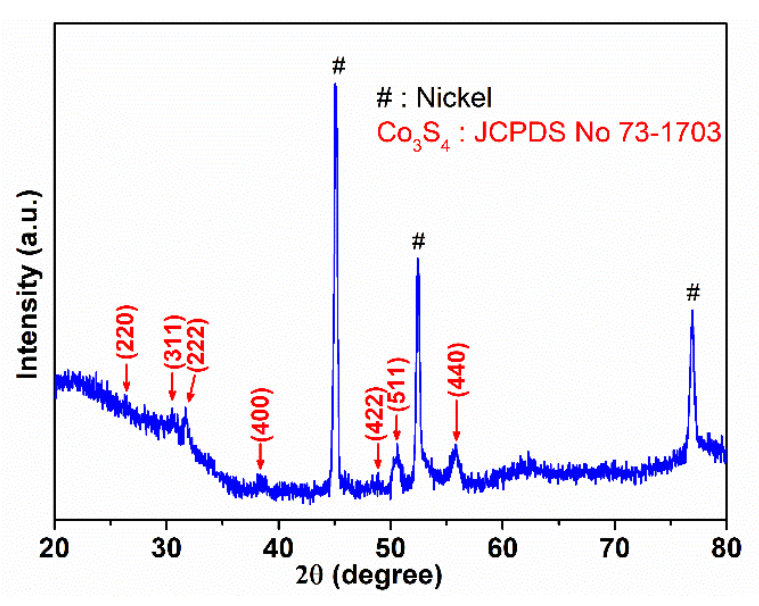

Figure 3. $\mathrm{XRD}$ analysis of $\mathrm{MnCo}_{2} \mathrm{~S}_{4}$ nanowires.

The raman spectrum of $\mathrm{MnCo}_{2} \mathrm{~S}_{4}$ nanowires is given in figure 5. There are two sharp raman peaks at $517 \mathrm{~cm}^{-1}$ and $636 \mathrm{~cm}^{-1}$ of $\mathrm{MnCo}_{2} \mathrm{~S}_{4}$ nanowires. The peaks in $636 \mathrm{~cm}^{-1}$ and $517 \mathrm{~cm}^{-1}$ are due to the lattice vibration and streching mode between $\mathrm{Mn}-\mathrm{S}$, respectively (Sahoo and Rout 2016).

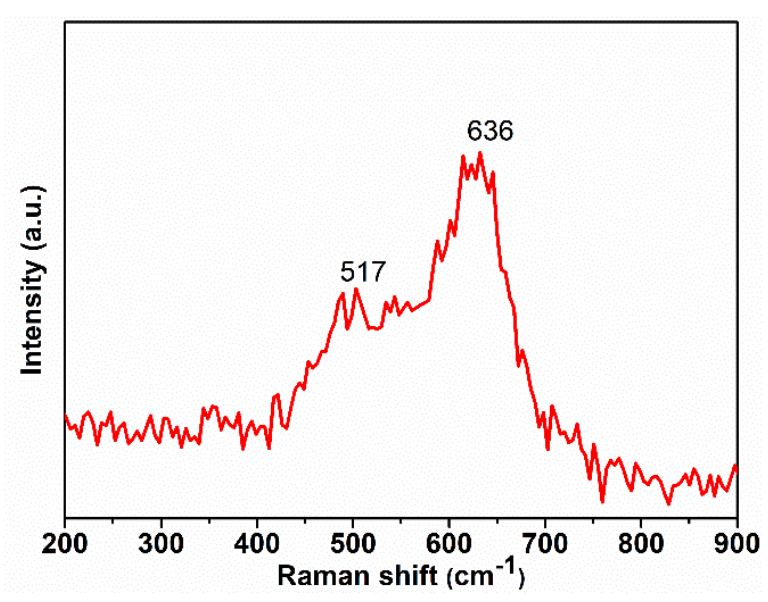

Figure 4. Raman spectrum of $\mathrm{MnCo}_{2} \mathrm{~S}_{4}$ nanowires.

The CV and GCD measurements are shown in Figure 5 and Figure 6, respectively. In CV measurement taken in the range of $0.25-0.3$
$\mathrm{mV}$, the current increased as the scanning rate increased.

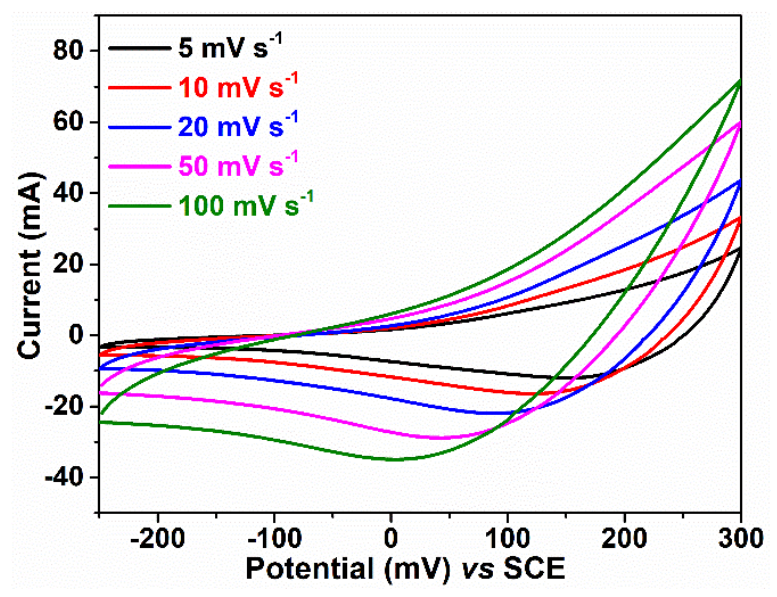

Figure 5. CV curve of different scanning rates.

In addition, the curves in Figure 6 where GCD results are obtained at current densities of $0.5,1,2,5$ and $10 \mathrm{~A} \mathrm{~g}^{-1}$ also showed nonlinear charge-discharge profile.

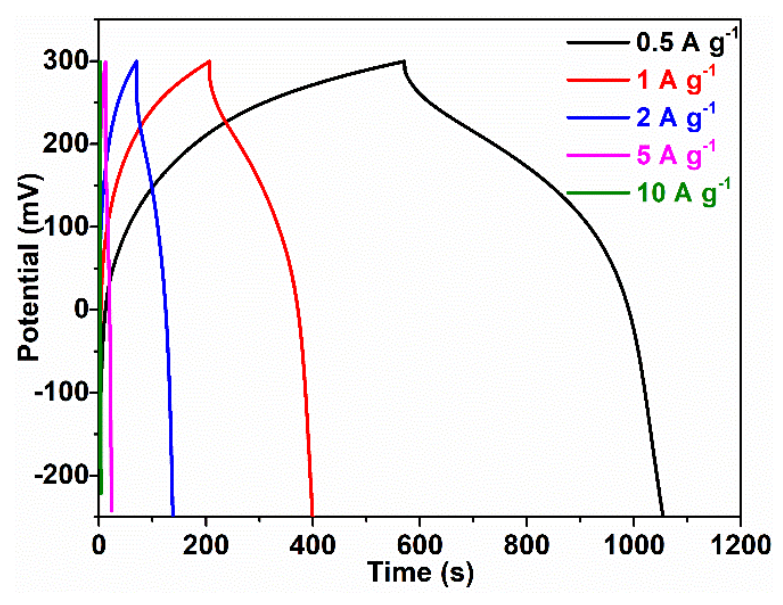

Figure 6. GCD measurement at different current densities.

The specific capacitance values calculated in discharge current densities of $0.5,1,2,5$ and $10 \mathrm{~A} \mathrm{~g}^{-1}$ were found to be 450, 363, 273, 130 and $58 \mathrm{~F} \mathrm{~g}^{-1}$, respectively (Figure 7). Because 
of voltage drop and insufficient active material involved in redox reaction at a higher current density, the specific capacitance slowly decreased at higher current density.

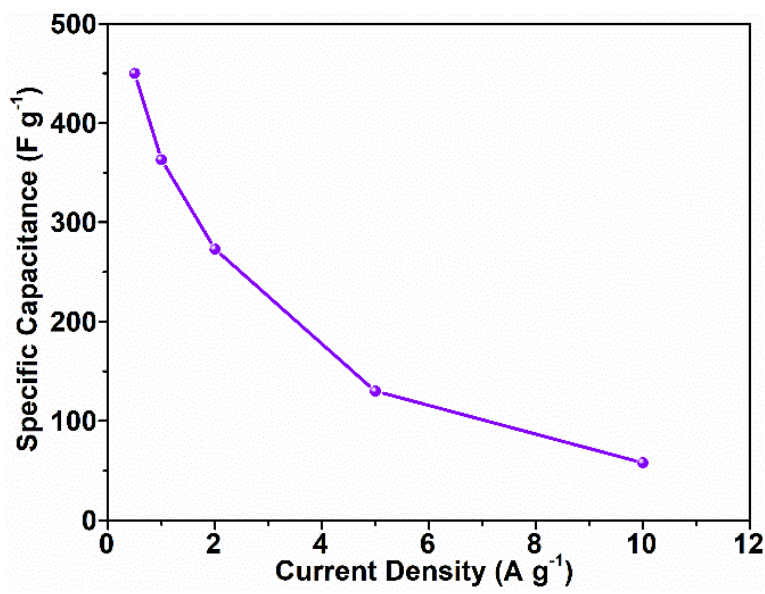

Figure 7. Specific capacitance as a function of discharge current.

The long-term cyclic stability of electrode material determined by the GCD method at a current density of $5 \mathrm{~A} \mathrm{~g}^{-1}$ is also shown in Figure 8. The $\mathrm{MnCo}_{2} \mathrm{~S}_{4}$ nanowire electrode material retains $46 \%$ of its original specific capacitance after 3000 charge-discharge cycles at a current density of $5 \mathrm{~A} \mathrm{~g}^{-1}$.

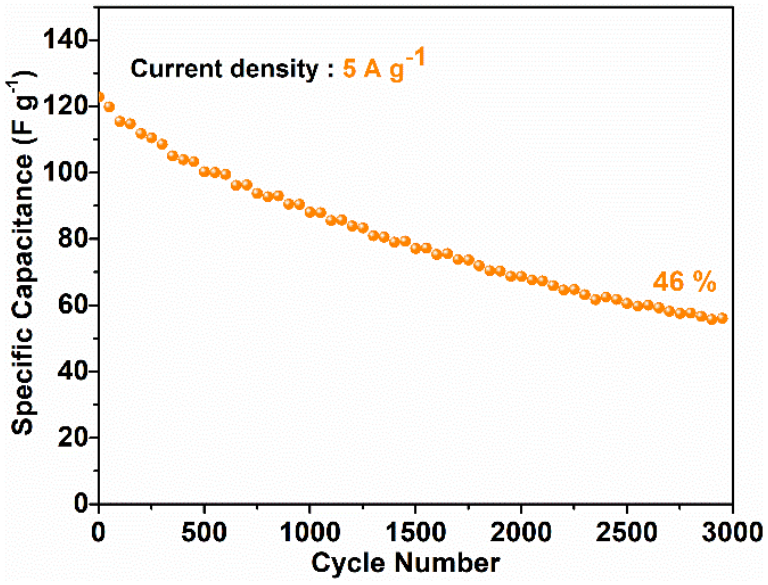

Figure 8. Cycling performance of $\mathrm{MnCo}_{2} \mathrm{~S}_{4}$ nanowire electrode.

\section{Conclusion}

As a result, $\mathrm{MnCo}_{2} \mathrm{~S}_{4}$ nanowires were successfully fabricated on $3 \mathrm{D}-\mathrm{Ni}$ foam in two-step by hydro-thermal method. The specific capacitance value was found to be $450 \mathrm{~F} \mathrm{~g}^{-1}$ at a current density of $0.5 \mathrm{~A} \mathrm{~g}^{-1}$. Furthermore, the sample showed excellent cycle stability after 3000 charge-discharge cycles, maintaining $46 \%$ of the initial specific capacitance. These results indicated that 3D-Ni foam@ $\mathrm{MnCo}_{2} \mathrm{~S}_{4}$ could be used as a supercapacitor electrode material.

\section{Acknowledgements}

This study was supported by EUBAP (Project Number: FBA-2017-468). We would like to thank the Erzincan Binali Yıldırım University Faculty of Science Application and Research Center (EUTAM) for their support in our analysis.

\section{References}

Beka, L. G., Li, X., Xia, X., \& Liu, W. (2017). 3D flower-like $\mathrm{CoNi}_{2} \mathrm{~S}_{4}$ grown on graphene decorated nickel foam as high performance supercapacitor. Diamond and Related Materials, 73, 169-176.

Burke, A. (2000). Ultracapacitors: why, how, and where is the technology. Journal of power sources, 91(1), 37-50.

Ghosh, D., \& Das, C. K. (2015). Hydrothermal growth of hierarchical $\mathrm{Ni}_{3} \mathrm{~S}_{2}$ and $\mathrm{Co}_{3} \mathrm{~S}_{4}$ on a reduced graphene oxide hydrogel@ Ni foam: a high-energy-density 
aqueous asymmetric supercapacitor. ACS applied materials \& interfaces, 7(2), 11221131.

Liu, S., \& Jun, S. C. (2017). Hierarchical manganese cobalt sulfide core-shell nanostructures for high-performance asymmetric supercapacitors. Journal of Power Sources, 342, 629-637.

Moosavifard, S. E., Fani, S., \& Rahmanian, M. (2016). Hierarchical $\mathrm{CuCo}_{2} \mathrm{~S}_{4}$ hollow nanoneedle arrays as novel binder-free electrodes for high-performance asymmetric supercapacitors. Chemical

Communications, 52(24), 4517-4520.

Nguyen, V. A., Lamiel, C., Shim, J. J. (2015). Hierarchical mesoporous graphene@ $\mathrm{Ni}-\mathrm{Co}-\mathrm{S}$ arrays on nickel foam for highperformance supercapacitors. Electrochimica Acta, 161, 351-357.

Peng, T., Qian, Z., Wang, J., Song, D., Liu, J., Liu, Q., \& Wang, P. (2014). Construction of mass-controllable mesoporous $\mathrm{NiCo}_{2} \mathrm{~S}_{4}$ electrodes for high performance supercapacitors. Journal of Materials Chemistry A, 2(45), 19376-19382.

Rolison, D. R., \& Nazar, L. F. (2011). Electrochemical energy storage to power the 21st century. Mrs Bulletin, 36(7), 486-493.

Sahoo, S., \& Rout, C. S. (2016). Facile electrochemical synthesis of porous manganese-cobalt-sulfide based ternary transition metal sulfide nanosheets architectures for high performance energy storage applications. Electrochimica Acta, 220, 57-66.

Simon, P., Gogotsi, Y., \& Dunn, B. (2014). Where do batteries end and supercapacitors begin?. Science, 343(6176), 1210-1211.
Xu, X., Tian, X., Li, X., Yang, T., He, Y., Wang, K., ... \& Liu, Z. (2019). Structural and chemical synergistic effect of $\mathrm{NiCo}_{2} \mathrm{~S}_{4}$ nanoparticles and carbon cloth for high performance binder-free asymmetric supercapacitors. Applied Surface Science, 465, 635-642.

Yang, Z., Zhang, J., Kintner-Meyer, M. C., Lu, X., Choi, D., Lemmon, J. P., \& Liu, J. (2011). Electrochemical energy storage for green grid. Chemical reviews, 111(5), 35773613.

Yu, M., Li, X., Ma, Y., Liu, R., Liu, J., \& Li, S. (2017). Nanohoneycomb-like manganese cobalt sulfide/three dimensional graphenenickel foam hybid electrodes for high-rate capability supercapacitors. Applied Surface Science, 396, 1816-1824.

Yu, Z., Tetard, L., Zhai, L., \& Thomas, J. (2015). Supercapacitor electrode materials: nanostructures from 0 to 3 dimensions. Energy \& Environmental Science, 8(3), 702-730.

Zhang, Y., Ma, M., Yang, J., Huang, W., \& Dong, X. (2014). Graphene-based threedimensional hierarchical sandwich-type architecture for high performance supercapacitors. RSC Advances, 4(17), 84668471. 